
\title{
$\angle S$ Research Square \\ Quantification of Airborne Concentrations of Nano And Micro Scale Phosphor Particles In The Manufacturing environment by Spectrofluorometric Method
}

\section{Fatih Deniz}

Dokuz Eylul University

Kadriye Ertekin ( $\nabla$ kadriye.ertekin@deu.edu.tr)

Dokuz Eylul University https://orcid.org/0000-0001-9819-3610

Utku Ulucan

Dokuz Eylul University

\section{Research Article}

Keywords: Airborne dust concentration, particle concentration, fluorescence, luminescence, method development, workplace hygiene

Posted Date: September 20th, 2021

DOl: https://doi.org/10.21203/rs.3.rs-831943/v1

License: (a) (1) This work is licensed under a Creative Commons Attribution 4.0 International License.

Read Full License 


\section{Abstract}

In this work, nanoscale luminescent materials dispersed in the air were collected and quantified by the fluorescence spectroscopy. A well-known phosphor; $\mathrm{LuAG}: \mathrm{Ce}^{3+}$ was chosen as the model particle due to its strong, measurable and repeatable signal which can easily be excited by the blue light and emits at yellow wavelengths. The ionic liquid modified polymethylmethacrylate based filters were fabricated by electrospinning technique. Samples were collected by means of a vacuum pump from the laboratory environment during the grinding, weighing, transfer, washing, drying and packaging of the phosphorus particles, for different time intervals. The spectrofluorometric method was used for the quantification of the airborne concentration of the nano and microscale dusts. Presented method was also tested in terms of precision, LOD, LOQ, and stability. To the best of our knowledge, this is the first attempt to measure the airborne concentrations of the nano-scale luminescent phosphor particles and can easily be adopted for the quantification of other nanoscale- emitting particles in workplaces. Additionally, the offered design allows miniaturization since it is possible to excite the particles with cost-effective LED based light sources, integrate the system with fiber optics and detect the received optical response by photodiodes.

\section{Introduction}

Today, engineered nanoscale materials provide promising commercial applications and advancements in different fields of technology, including electronics, imaging, textile, and even therapeutics [1-5]. As a result of their wide usage area and benefits, they have started to be produced very widely on an industrial scale. On the other hand, concerns have been raised about their possible health effects for conditions where the NPs will become aerosolized and consequent particle uptake via inhalation, and their retention in the body. Therefore, in the last two decades, determination of the airborne concentration of nano-scale particles resulting from the manufacturing processes have received the attention of the scientific community $[6,7]$.

However, identification, quantification, and characterization of nanopatricles (NPs) pose a significant challenge on analytical point of view because the NPs are usually present at low concentrations and are invisible even for the analytical instruments. Several publications described some suitable techniques for the characterization of the NPs, including electron microscopy [8], Inductively Coupled Plasma Mass Spectrometry (ICP-MS) [9], Dynamic Light Scattering (DLS) [10,11], X-ray Diffraction (XRD) methods [12], Scanning Electron Microscopy (SEM), transmission electron microscopy (TEM), atomic force microscope (AFM) [13], cryo-SEM and -TEM, and many others.

In two different Works, Cölfen et al. used analytical ultracentrifugation (AUC) in an integrated manner by fluorescence measurements to separate and indicate the components of the sample $[14,15]$.

Batsungnoen and colleagues collected and characterized airborne nanoparticles of the cement industry during drilling and polishing processes using scanning mobility particle sizer, portable aerosol spectrometer, diffusion size classifier, transmission electron microscopy (TEM), scanning electron microscope -energy dispersive X-ray (SEM-EDX), and, X-ray diffraction spectroscopy [16]. 
Boonruksa et al. investigated airborne nanoparticle and carbon nanotube (CNT) exposures from polypropylene composites generated during injection molding and grinding processes. The CNTs used in this study were long, rope-like MWCNTs, with an average diameter of $\sim 10 \mathrm{~nm}$ and length in between 0.5$5 \mu \mathrm{m}$. A combination of real-time and time-integrated sampling was used to collect and characterize the nano-aerosol emissions. Characterization was performed by total particle number concentration (TPNC) and particle size distribution measurements, particle morphology, and trace metal analysis by ICP-MS [6]. Brame and co-workers studied workplace exposure of nanomaterials released from carbon nanotubeenabled anti-corrosive coatings. Characterization of the material included SEM and Raman spectroscopy to confirm the presence of the MWCNTs and zinc, and assess particle size to determine if the primary particle or fiber diameter merits nano-specific consideration (particles $<100 \mathrm{~nm}$ in at least one dimension) [17]. In another work, airborne particle release during the spray application of coatings was analyzed in the nanometer and micrometer size range where SEM-, TEM- and EDX-analyses on electrostatically deposited spray aerosol particles were performed [18].

Efforts on the improvement of methods to quantify the release and characterization of the engineered nanomaterials (ENMs) are continuing. However, there is a wide diversity in these methods. A summary of the recent works indicating the type of the aerosol emissions and characterization technique of the regarding material was shown in Table 1. 
Table 1

A summary of the characterization technique for nano materials

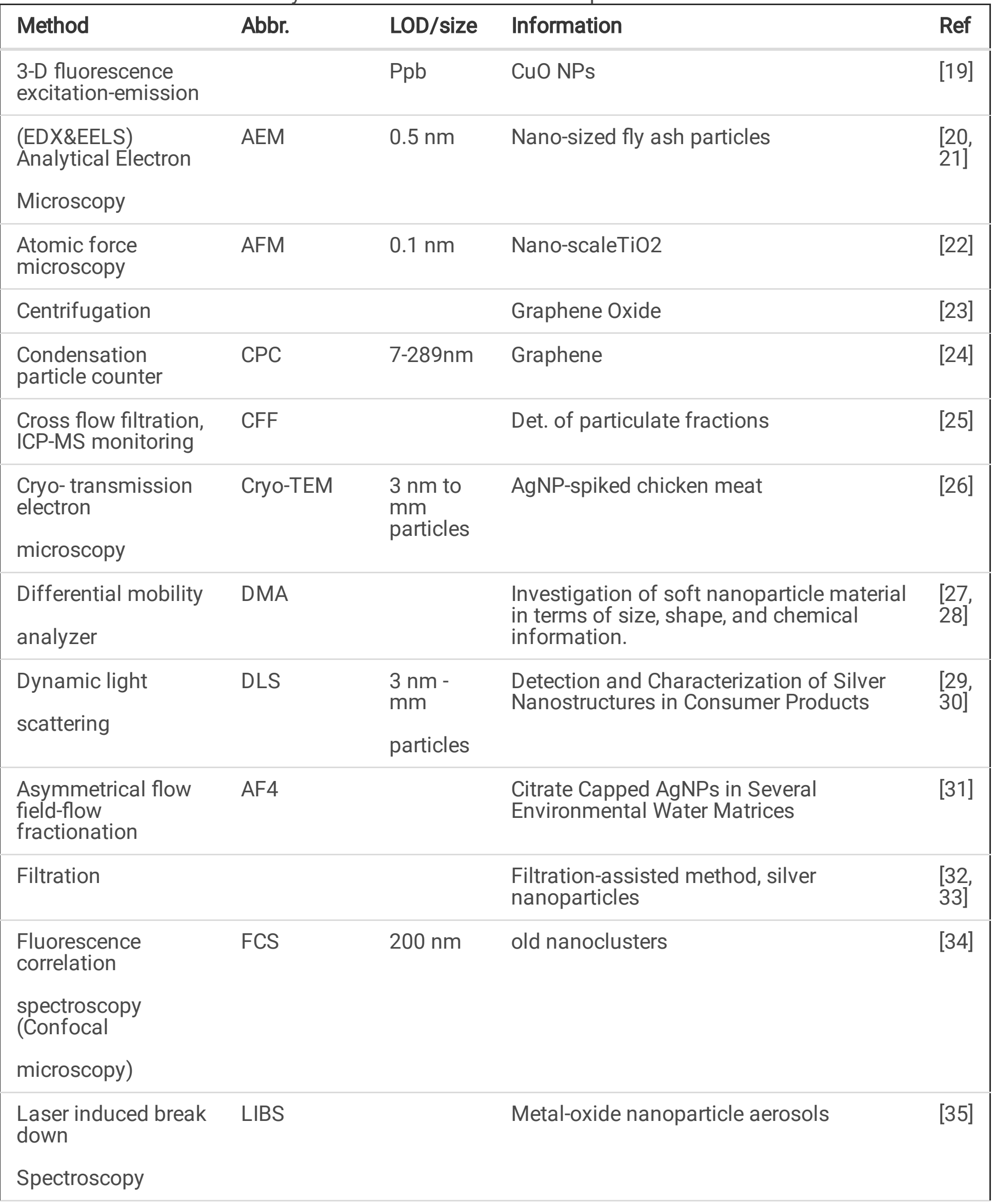




\begin{tabular}{|c|c|c|c|c|}
\hline Method & Abbr. & LOD/size & Information & Ref \\
\hline \multirow[t]{2}{*}{ Membrane filtration } & & $\begin{array}{l}\text { Mainly } \\
0.2 \& 0.4 \\
\mathrm{~mm}\end{array}$ & Nacomposite membrane & [36] \\
\hline & & $\begin{array}{l}\text { filtration } \\
\text { steps }\end{array}$ & & \\
\hline $\begin{array}{l}\text { Moessbauer } \\
\text { spectroscopy }\end{array}$ & Moessbauer & & Bare iron oxide samples & [37] \\
\hline $\begin{array}{l}\text { Raman } \\
\text { spectroscopy }\end{array}$ & Raman & & Tungsten oxide nanoparticles & [38] \\
\hline $\begin{array}{l}\text { Scanning electron } \\
\text { microscopy }\end{array}$ & SEM & $\begin{array}{l}1 \mathrm{~nm} \text { to } 1 \\
\mathrm{~mm}\end{array}$ & $\mathrm{CeO} 2$ and $\mathrm{TiO} 2$ & [39] \\
\hline $\begin{array}{l}\text { Scanning mobility } \\
\text { particle } \\
\text { sizer }\end{array}$ & SMPS & & $\begin{array}{l}\text { Nano-containing consumer spray } \\
\text { products }\end{array}$ & [40] \\
\hline $\begin{array}{l}\text { Scanning } \\
\text { transmission } \\
\text { electron microscopy }\end{array}$ & STEM & $<0,1 \mathrm{~nm}$ & TiO2-NPs & [41] \\
\hline $\begin{array}{l}\text { Scanning } \\
\text { Transmission } \\
\text { X-ray Microscopy }\end{array}$ & STXM & $30 \mathrm{~nm}$ & TiO2-NPs & [41] \\
\hline $\begin{array}{l}\text { Single particle mass } \\
\text { spectromete }\end{array}$ & SPMS & & Titanium dioxide (E 171) & [42] \\
\hline $\begin{array}{l}\text { Static light } \\
\text { scattering }\end{array}$ & SLS & & Gold nano clusters & [43] \\
\hline $\begin{array}{l}\text { Time-of-flight mass } \\
\text { spectrometry }\end{array}$ & TOF-MS & ppb-ppt & $\begin{array}{l}\text { Diesel exhaust } \\
\text { Particles }\end{array}$ & [44] \\
\hline $\begin{array}{l}\text { Transmission } \\
\text { electron } \\
\text { microscopy }\end{array}$ & TEM & $>0.1 \mathrm{~nm}$ & Cu-doped ZnO-Ag nanoparticles & [45] \\
\hline $\begin{array}{l}\text { UV/Vis } \\
\text { spectroscopy }\end{array}$ & UV-Vis & & $\mathrm{Ag} / \mathrm{Al} 203$ & [46] \\
\hline
\end{tabular}




\begin{tabular}{|c|c|c|c|c|}
\hline Method & Abbr. & LOD/size & Information & Ref \\
\hline \multirow{4}{*}{$\begin{array}{l}\text { Wet scanning } \\
\text { electron } \\
\text { microscopy }\end{array}$} & WetSEM & $\begin{array}{l}\text { Low } \\
\text { contrast } \\
\text { samples: }\end{array}$ & $\mathrm{AgBr} / \mathrm{ZnO}$ & {$[47]$} \\
\hline & & $100 \mathrm{~nm}$ & & \\
\hline & & $\begin{array}{l}\text { High } \\
\text { contrast } \\
\text { samples: }\end{array}$ & & \\
\hline & & $10 \mathrm{~nm}$ & & \\
\hline $\begin{array}{l}\text { X-ray absorption } \\
\text { spectroscopy }\end{array}$ & XAS & ppm & CuO Nanoparticles & [48] \\
\hline $\begin{array}{l}\text { X-ray fluorescence } \\
\text { spectroscopy }\end{array}$ & $\mathrm{XRF}$ & & Graphite oxide & [49] \\
\hline X-ray microscopy & XRM & $30 \mathrm{~nm}$ & $\mathrm{MoO} 2$ & {$[50]$} \\
\hline
\end{tabular}

In this study, we proposed a sensitive method for the determination of airborne concentrations of nano and micro-sized phosphor particles by monitoring the luminescence properties of the emitting particles as the analytical signal. Luminescence-based techniques are probably the most sensitive among the spectral measurement methods [51]. However, for a substance to be measured with this technique, first of all, it should exhibit luminescence properties. On the other hand, developments in nanotechnology have greatly increased number of the luminescent materials. For example, although metallic silver and gold do not have luminescence response in their bulk form, they exhibit significant emission at measurable levels when they are scaled to nano-size [52-55]. Similarly, the spectral behavior of the metal oxides of ZnO, $\mathrm{CuO}$, and $\mathrm{TiO}_{2}$, and, carbon-based materials, which are widely used in nanoscale in industry, are in the same direction [56-60,45]. The emission based approach; used in the design of many optical sensors today, can easily be integrated with LED light sources, photodiodes and fiber optics, which allow miniaturization and practical usage of the measuring devices in the field [61,62]. Therefore, when the excitation and emission wavelength has been determined, the offered luminescence-based method may be promising for the selective quantification of airborne concentrations of the nano-scale luminescent materials.

On the other hand, phosphors are solid materials that exhibit fluorescence, or phosphorescence, when exposed to a radiation in ultraviolet or visible region, or an electron beam. Today, tens of thousands of phosphors emitting in violet, blue, green and red wavelengths have been synthesized. Among them, a group of materials including LuAG: $\mathrm{Ce}^{3+}$ are produced on a large scale and extensively used in the production environments of screens, electronic materials and LED based light sources. In this study, the nano-scale grinded form of the LuAG: $\mathrm{Ce}^{3+}$ was chosen as the model particle which can easily be excited 
by the blue light and emits at yellow wavelengths. The LuAG: $\mathrm{Ce}^{3+}$ was also preferred because of its strong, measurable and repeatable signal which can easily be calibrated.

For this purpose, samples were collected by means of a vacuum pump for 9 hours from the lab environment where nano-sized powders were produced and the grinding, weighing, transfer, washing, drying and packaging of the phosphorus particles were carried out. The nano-scale $(300-500 \mathrm{~nm})$ particles were deposited on electro-spun polymethyl methacrylate fibers. The spectrofluorometric method was used in the qualitative and quantitative analysis of the samples. To the best of our knowledge, this is the first attempt to measure the airborne concentrations of the nano-scale luminescent phosphorus particles and can easily be adopted for the quantitative determination of other nanoscale- emitting particles during manufacturing and handling, in workplaces.

\section{Experimental}

\subsection{Chemicals}

Mid molecular weight Polymethyl methacrylate; PMMA (avg. MW 350,000 $\mathrm{g} \mathrm{mol}^{-1}$ ) Analytical grade tetrahydrofuran, room temperature ionic liquid; 1-Butyl-3-methylimidazolium tetrafluoroborate (BMIMBF 4$)$, diisooctyl phthalate and absolute ethanol were supplied from Sigma Aldrich Corporation. Millipore Purelab ultrapure water was used throughout the studies. The green phosphor; $\mathrm{Lu}_{3} \mathrm{Al}_{5} \mathrm{O}_{12}: \mathrm{Ce}^{3+}$ (LuAG: $\mathrm{Ce}^{3+}$ ) was provided from Mitsubishi Chemicals Corporation.

\subsection{Instrumentation}

Steady-state excitation/emission spectra of the phosphor powders and composites were recorded by FLS920 spectrofluorometer from Edinburgh Instruments which works on time correlated single photon counting (TCSPC) mode. The LuAG particles were grinded by a Fritsch pulveristte 7-type device. Particle morphologies of the samples were clarified by a Zeiss Sigma 500 field emission scanning electron microscope. Precision balance (Denver Instrument SI-234) and Malvern Nano ZS instruments were used for weighing and size distribution measurements, respectively.

\section{Results And Discussion}

\subsection{The work environment}

It is critically important to work in a particle-free environment when you're working with nanoscale-sized particles. Therefore, test materials and calibration standards were prepared in a laboratory environment with a floor area of $780 \times 960 \mathrm{~cm}^{2}$, satisfying the clean air requirements of ISO class 5 in operation. The classification has been performed using desecrate particle counter with a flow rate of $25 \mathrm{~L} / \mathrm{min}$. considering the particle size range of $D \geq 0.3$ and $D \geq 0.5 \mu \mathrm{m}$. The standard preparation grinding and sampling processes were performed in this room. The scheme of the laboratory is shown in Fig. 1. 


\section{2 Choice of indicator material}

Phosphors are intensively used as raw material in production of light emitting diodes (LED) and other electronic materials including cathode ray tubes, field emission displays, and plasma display panels. Most of them are solid inorganic materials consisting of a host lattice, usually intentionally doped with a rare-earth or transition metal, or both of them. They emit light, or luminesces, when exposed to ultraviolet or visible light or an electron beam. The absorption of energy takes place via either the host lattice or on dopants and/or co-dopants taking place in the structure of the phosphor. In this work, commercially available $\mathrm{Ce}^{3+}$ activated Lutetium aluminum garnet $\left(\mathrm{LuAG}: \mathrm{Ce}^{3+}\right)$ was chosen as indicator material and has been subject of the quantification studies due to its bright luminescence, structural stability, particle size, and resistance towards air, water, $\mathrm{pH}$ variations, and, oxidizing and reducing agents, respectively. Fig. 2 reveals light-induced excitation and emission behavior of the $\mathrm{Ce}^{3+}$ activated LuAG powders. The two excitation maximum of the phosphor centered at 346 and $450 \mathrm{~nm}$, arises from the $2 \mathrm{~F} 7 / 2 \rightarrow 5 \mathrm{~d} 1$ and $2 \mathrm{~F} 5 / 2 \rightarrow 5 \mathrm{~d} 2$ transitions of the $\mathrm{Ce}^{3+}$, respectively. The broad band emission peak centered at $540 \mathrm{~nm}$ can mainly be attributed to the back transitions of the excited electrons from the $5 \mathrm{~d}$ to the $4 \mathrm{f}$ orbitals of the trivalent cerium $[63,64]$. In a similar way, the PMMA encapsulated LuAG exhibited a bright luminescence located at $512 \mathrm{~nm}$ when excited by the energy of the $450 \mathrm{~nm}$ of light (See Fig. 2). In this work, the intense emission of the LuAG:Ce ${ }^{3+}$ has been followed as the analytical signal to perform the quantification of nano-scale dusts in the air of the workplace, in form of aerosols. Since the selectivity of an analytical method is its ability to measure accurately the analyte in the presence of other potential interferences, the specific and concentration dependent signal observed at $512 \mathrm{~nm}$, provided sufficient selectivity for the offered method. Herein, we used the certain concentrations of the LuAG:Ce ${ }^{3+}$ as standards for the calibration process as it has been convenient in spectral studies [65].

\subsection{Grinding of the LuAG:Ce ${ }^{3+}$ particles}

During grinding studies, $250 \mathrm{mg}$ and $19 \mu \mathrm{m}$ of phosphor samples were subjected to milling for three consecutive time periods of 120 minutes. Grinding balls were selected in appropriate number and diameter for the desired grinding size. For the first and second 120 minutes of grinding periods, $10 \mathrm{~g}$ of balls of $10 \mathrm{~mm}$ in diameter were used in each crucible. For further 120 minutes of grinding, $40 \mathrm{~g}$ of balls with a diameter of $2 \mathrm{~mm}$ was used. No lubricant is used for the balls and crucibles during grinding. Powders were added into the crucibles after precise weighing. Fig. 3 and 4 reveal SEM photographs of the phosphor particles before and after grinding, and, size distribution analysis results of the samples, respectively. At the end of the total grinding time of 360 minutes, the particle sizes were clustered in three groups; presenting average particle diameters of $233 \pm 58$ (13\%), $1431 \pm 440$ (78\%) and $5265 \pm 434 \mathrm{~nm}$ $(9 \%)$, respectively. The diversity in particle size and morphology observed in the SEM photographs is in accordance with the results depicted in size distribution analysis. Since the variation in particle sizes can also be seen in real working environments, the powders obtained by this way were subjected to transfer, washing, drying, weighing, and other processes without further grinding.

\section{4 Preparation of the electrospun fibers}


The electrospinning technique was used as a simple way to fabricate the filter materials. Mid-molecular weight polymethylmethacrylte (PMMA) along with ionic liquid and the plasticizer was used to produce the electrospun fibers. The optimum precursor composition to form bead-free continuous fibers was provided_by mixing $480 \mathrm{mg}$ of polymethylmethacrylte (PMMA), $240 \mathrm{mg}$ of plasticizer and $96 \mathrm{mg}$ of ionic liquid in $6.0 \mathrm{~mL}$ of THF. After $8 \mathrm{~h}$ of stirring in the closed vial, the homogenous mixture was transferred into a $10 \mathrm{~mL}$-plastic syringe. The solution flow rate was maintained at $0.5 \mathrm{~mL} / \mathrm{h}$ by using the programmable syringe pump. An electric potential of $28 \mathrm{kV}$ was applied between the needle of the plastic syringe and the aluminum substrate. Under the high tension, a Taylor cone; a jet of charged species; at the tip of the syringe body was formed, and the electrospinning took place. The resulting fibers collected on the substrate exhibited structural stability and integrity. The scanning electron microscope (SEM) images of the fibers under different magnification were shown in Fig. 5 Average fiber diameter was calculated by using at least 40 representative data points and reported as $657 \pm 78 \mathrm{~nm}$. Presence of nonvolatile room temperature ionic liquid, $\mathrm{BMIMBF}_{4}$ in the polymer provided excellent ionic conductivity during electrospinning. Although the imidazolium based ionic liquids have a reported absorption and emission in the visible side of the electromagnetic spectrum, the measured fluorescence of the $\mathrm{BMIMBF}_{4}$ was negligible in comparison to the strong emission of the dusts, and, did not suppress the indicating ability of the LuAG:Ce3+ in any way. The fabricated material was weighed on a precision balance and stored above the diffuser of the air pump. Fig. 5 shows SEM photographs of the fabricated electrospun fibers under different magnification before and after filtration process.

\section{5 Preparation of calibration standards}

Calibration standards are critically important for the analytical process since they are used to draw the calibration curve with a high accuracy. In this study, the standards were prepared by using the high purity and strongly emitting LuAG particles at five different concentration points. The same composition offered for the electrospun fibers was used in the preparation of the matrix material of calibration standards. Amount of the phosphor for each calibration standard was adjusted as 1.0, 2.0, 3.0, 4.0 and $5.0( \pm 0.07) \mathrm{mg}$ phosphor/kg polymer; respectively. The resulting composites were spread onto a $125 \mu \mathrm{m}$ polyester support (Mylar TM type) with a knife-spreading device. Thicknesses of the films were measured using Tencor Alpha Step 500 Profilometer and the average film thickness was found to be $10.31 \mu \mathrm{m}$ $(n=8)$. Each sensing film was cut to size $1.2 \times 2.5 \mathrm{~cm}$, fixed in the measurement cell of the spectrofluorometer, and the excitation/emission spectra were recorded for five different calibration points.

\subsection{Calibration plot, limit of detection (LOD) and limit of quantification (LOQ)}

In general, calibration of an instrumental method is very important and should be considered as the key point of the method validation. In the calibration process the use of correlation and/ determination coefficients as a test for linearity, the homoscedasticity of the experimental data, selection of appropriate weighting factor, and the regression, all are very important [66]. Herein the calibration plot was derived by using emission based response of the thin films. Fig. 6-I reveals excitation/emission spectra of the LuAG doped thin films acquired for five different concentration points upon excitation at $450 \mathrm{~nm}$. The very 
strong and repeatable emission signal observed at $512 \mathrm{~nm}$ has been followed as the analytical signal. Emission intensities (dependent variable) were plotted versus corresponding phosphorus concentrations (independent variable) for five different concentration points. This study was repeated five times with five separate films for each calibration point. The resulting calibration plot derived using least squares method can be defined by the equation and $R^{2}$ values of $y=8 \times 10^{7} x-6488$ and $R^{2}=0.9799$, respectively. Generally, a value of $\mathrm{R}^{2}$ greater than 0.990 is desirable. However, this is not the sole parameter in the evaluation of the linearity and is more realistic for the solution phase measurements where preparation of the calibration standards is easier than that of the solid state. Herein when the calibration standards and test numbers were considered, the obtained $\mathrm{R}^{2}$ value of 0.9799 looks like satisfactory for the solid state. The resulting calibration plot including error bars was shown in Fig. 6-II. The repeatability has been confirmed by using the 5 different graphical plots exhibiting standard deviations on the $y$ axes for means less than $7.0 \%$.

Limit of detection (LOD) has been approximated based on the standard deviation of the response (Sy) of the calibration curve and the slope of the calibration plot (S) according to the formula: $L O D=3.3(\mathrm{Sy} / \mathrm{S})$. We determined the limit of quantification (LOQ) considering the lowest calibration standard on the calibration curve as the initial point where the detection response for the analyte was at least five times over the blank [66]. The upper limit of quantification (ULOQ) is estimated as the highest calibration standard on the calibration curve, where the analyte response was reproducible, and the precision and accuracy were within $15 \%$ of the coefficient of variation and $15 \%$ of the nominal concentration, respectively. Therefore, the LOD and LOQ were found to be $0.7 \mathrm{mg}$ phosphor/ $\mathrm{Kg}$ polymer and between 1.4-4.7, mg phosphor/Kg polymer, respectively.

\section{7 Stability}

Many analytes may have a potential to readily decompose prior to measurement, during the preparation of the sample, transfer, extraction, or during storage. Therefore, it is necessary to clarify for the method how long a standard or sample can be stored before the analysis. Herein we tested spectral signal of the bare and PMMA embedded phosphors in air, water, in the presence of corrosive vapors of $\mathrm{HCl}$, and in solutions of strong-oxidizing acid (2.0 of $\left.\mathrm{M} \mathrm{HNO}_{3}\right)$ and strong base $(2 \mathrm{M} \mathrm{NaOH})$, after $12 \mathrm{~h}$ of exposure. While the bare phosphors stored in the alkaline solution exhibiting a signal drop of 5.0\%, the PMMA embedded forms yielded almost the same emission intensity at $512 \mathrm{~nm}$. Additionally, long-term photostability of the phosphor based thin films has been tested after 12 months' storage in a desiccator in the Lab. environment. The observed signal drift was only $4.0 \pm 0.6 \%(n=10)$ in direction of decrease in signal intensity, which can be concluded as an evidence of excellent short and long time stability the offered test materials.

\section{8 Processes, sampling and spectral measurements for real samples}

The sampling of nano-scale particles from the air of the production lab. was performed via the vacuum pomp during the processes of weighing, grinding, emptying the crucibles and the final weighing. The 
grinding of each sample was performed at three different steps, with $10 \mathrm{~mm}$ diameter balls, at two consecutive speeds of 350 and $750 \mathrm{rpm}$, and, with $1 \mathrm{~mm}$ diameter balls, at 750rpm, respectively. During the procedures, dusts in the ambient air were deposited on nano-sized PMMA filters for 3.0, 6.0 and 9.0 $\mathrm{h}$ of time periods. At the end of each sampling step, the electrospun filters were collected, dissolved in $6 \mathrm{~mL}$ of THF under magnetic stirring and the obtained homogenous mixture was used in preparation of thin films, as made for the calibration standards. Fig. 7 shows recorded excitation and emission spectra for the real samples after grinding durations of 120,240 and $360 \mathrm{~min}$. which corresponds to 3.0, 6.0 and 9.0 $\mathrm{h}$ of total processing time in the clean room along with other handling processes.

The spectral signals were computed via the calibration plot and converted to the airborne dust concentration for the samples. Table 2 reveals the recorded spectral counts (fluorescence intensities) and corresponding dust concentrations for the certain time ranges for two consecutive days. The presented emission based data and the calibration plot were the average of at least five replicate measurements. As can be seen from the table, the largest standard deviation of the counts and concentration measurements were less than 2.0 and $9.0 \%$, respectively. Recorded dust concentrations for the same time periods of the first and second days are in accordance with each other. Additionally, the calculated dust concentrations for the shortest time duration were above the LOD of the offered method.

Table 2. Recorded average spectral fluorescence intensities $(n=5)$ and corresponding airborne dust concentrations. The sample collection was performed during grinding times of 120, 240 and 360 min., and following handling processes, for two consecutive day

\begin{tabular}{|c|c|c|c|c|}
\hline & $1^{\text {st }}$ day & $\begin{array}{l}\text { Dust (mg dust/kg } \\
\text { polymer)*10 }\end{array}$ & $2^{\text {nd }}$ day & $\begin{array}{l}\text { Dust (mg } \\
\text { dust } / \mathrm{kg} \\
\text { polymer)*10-3 }\end{array}$ \\
\hline $\begin{array}{l}120 \text { min. of grinding, } 3 \mathrm{~h} \\
\text { of sampling }\end{array}$ & $43900 \pm 927$ & $0.6 \pm 0.010$ & $59800 \pm 1069$ & $0.8 \pm 0.009$ \\
\hline $\begin{array}{l}240 \text { min. of grinding } 6 \mathrm{~h} \\
\text { of sampling }\end{array}$ & $126689 \pm 2497$ & $1.8 \pm 0.012$ & $125555 \pm 3027$ & $1.7 \pm 0.011$ \\
\hline $\begin{array}{l}360 \mathrm{~min} \text {. of grinding, } 8 \mathrm{~h} \\
\text { of sampling }\end{array}$ & $139419 \pm 4875$ & $1.9 \pm 0.017$ & $159800 \pm 5127$ & $2.1 \pm 0.015$ \\
\hline
\end{tabular}

For this work, the measured airborne dust concentrations from the laboratory environment falls within the range given in the calibration plot, allowing accurate measurement of the real samples without any mathematical transformation operation. In case of lower or higher sample concentrations, the extrapolation of the linear calibration plot is possible. For further deviations, the range of the calibration standards can be tuned to some extent considering the rules of the spectral measurements which allows application of the fluorescence based sensing approach to the quantification of other nano-scale luminescent materials. 
Because exposure limits for other nanomaterials do not exist yet, herein we will compare our results and working range with the worker exposure limits of OSHA to nanoscale particles of $\mathrm{TiO}_{2}$ which recommends not exceed 0.3 milligrams per cubic meter $(\mathrm{mg} / \mathrm{m} 3)$ for 8 hours. The NIOSH's recommended exposure limit for fine-sized $\mathrm{TiO}_{2}$ particles (particle size greater than $100 \mathrm{~nm}$ ) is $2.4 \mathrm{mg} / \mathrm{m}^{3}$. The offered method also allows quantification of the dust concentration within these limits, without any conversion.

\section{Conclusion}

In this work we performed quantification of the nano-scale phosphor dusts by means fluorescence spectroscopy. Working range of the presented method falls within the range given by OSHA for the nanoscale particles. The idea lying behind this study was the utilization of the fluorescent based measurement skills to make the nano-scale dusts in the working environments visible and measurable quantitatively. Most of the metals including gold and silver and their oxides, and dusts of other industrial materials including carbon derivatives of graphene, graphite, multi wall carbon nano tubes, $\mathrm{TiO}_{2}, \mathrm{ZnO}$, and $\mathrm{CuO}$ become luminescent when the particle size was reduced to nano-scale. Therefore, the offered method may be promising for the quantification of nano-scale dusts. Additionally, the long-term effects of such nanoparticles on human health are not yet fully known. As the health effects and consequences become understood, it will become a necessity to detect their airborne concentrations in work environments in the future [67].

\section{Declarations}

\section{Acknowledgment}

We would like to thank to Dokuz Eylul University, Center for Fabrication and Application of Electronic Materials for allowing their laboratories to be used for sampling during long production, grinding and sampling processes.

\section{Author Declarations}

\section{Funding Information}

This research was mainly supported by the Scientific Research Funds of Dokuz Eylul University, (project number; 2019.KB.FEN.002).

\section{Conflicts of Interest}

The authors declare that they have no known competing financial interests or personal relationships that could have appeared to influence the work reported in this paper.

\section{Authors' contributions}


KE and FD offered and designed the working plan, and FD performed all of the experiments including pomp design, sampling, and spectroscopic measurements. FD and UU performed grinding experiments together. KE supervised the experiments. KE and FD analyzed the data and wrote the manuscript. All authors read and approved the final manuscript.

\section{Availability of data and material}

Authors confirm that the data generated and analysed during the current study are included in the submitted article files.

\section{Author information (Affiliations)}

Fatih Deniz: Dokuz Eylul University, The Graduate School of Natural and Applied Sciences, Program of Occupational Health and Safety, Buca, 35390, Izmir, Turkey

Kadriye Ertekin (Corresponding Author): University of Dokuz Eylül, Faculty of Science, Department of Chemistry, 35160 Buca Izmir Turkey

Utku Ulucan: Dokuz Eylul University, The Graduate School of Natural and Applied Sciences, Program of Nanoscience and Nano-engineering, Buca, 35390, Izmir, Turkey

Ethics approval/declarations: Not applicable

Consent to participate: Not applicable

Consent for publication: Not applicable

\section{References}

1. Adachi M, Murata Y, Takao J, Jiu J, Sakamoto M, Wang F (2004) Highly efficient dye-sensitized solar cells with a titania thin-film electrode composed of a network structure of single-crystal-like TiO2 nanowires made by the "oriented attachment" mechanism. J Am Chem Soc 126(45):14943-14949. https://doi.org/10.1021/ja048068s

2. Alivisatos $P$ (2000) Colloidal quantum dots. From scaling laws to biological applications. Pure Appl Chem 72(1-2):3-9. https://doi.org/10.1351/pac200072010003

3. Vo-Dinh T (2017) Nanotechnology in Biology and Medicine: Methods, Devices, and Applications, Second Edition, 2nd edn. CRC Press, https://doi.org/10.4324/9781315374581

4. West JL, Halas NJ (2003) Engineered nanomaterials for biophotonics applications: improving sensing, imaging, and therapeutics. Annu Rev Biomed Eng 5(1):285-292. https://doi.org/10.1146/annurev.bioeng.5.011303.120723

5. Wu X, Liu H, Liu J, Haley KN, Treadway JA, Larson JP, Ge N, Peale F, Bruchez MP (2003) Immunofluorescent labeling of cancer marker Her2 and other cellular targets with semiconductor 
quantum dots. Nat Biotechnol 21(1):41-46. https://doi.org/10.1038/nbt764

6. Boonruksa P, Bello D, Zhang J, Isaacs JA, Mead JL, Woskie SR (2016) Characterization of Potential Exposures to Nanoparticles and Fibers during Manufacturing and Recycling of Carbon Nanotube Reinforced Polypropylene Composites. Ann Occup Hyg 60(1):40-55. https://doi.org/10.1093/annhyg/mev073

7. Murdock RC, Braydich-Stolle L, Schrand AM, Schlager JJ, Hussain SM (2008) Characterization of nanomaterial dispersion in solution prior to in vitro exposure using dynamic light scattering technique. Toxicol Sci 101(2):239-253. https://doi.org/10.1093/toxsci/kfm240

8. Luo P, Morrison I, Dudkiewicz A, Tiede K, Boyes E, O'Toole P, Park S, Boxall AB (2013) Visualization and characterization of engineered nanoparticles in complex environmental and food matrices using atmospheric scanning electron microscopy. J Microsc 250(1):32-41. https://doi.org/10.1111/jmi.12014

9. Krystek P, Tentschert J, Nia Y, Trouiller B, Noel L, Goetz ME, Papin A, Luch A, Guerin T, de Jong WH (2014) Method development and inter-laboratory comparison about the determination of titanium from titanium dioxide nanoparticles in tissues by inductively coupled plasma mass spectrometry. Anal Bioanal Chem 406(16):3853-3861. https://doi.org/10.1007/s00216-013-7580-z

10. Marassi V, Casolari S, Roda B, Zattoni A, Reschiglian P, Panzavolta S, Tofail SA, Ortelli S, Delpivo C, Blosi M, Costa AL (2015) Hollow-fiber flow field-flow fractionation and multi-angle light scattering investigation of the size, shape and metal-release of silver nanoparticles in aqueous medium for nano-risk assessment. J Pharm Biomed Anal 106:92-99. https://doi.org/10.1016/j.jpba.2014.11.031

11. Wagner S, Legros S, Loeschner K, Liu J, Navratilova J, Grombe R, Linsinger TPJ, Larsen EH, von der Kammer F, Hofmann T (2015) First steps towards a generic sample preparation scheme for inorganic engineered nanoparticles in a complex matrix for detection, characterization, and quantification by asymmetric flow-field flow fractionation coupled to multi-angle light scattering and ICP-MS. J Anal Atom Spectrom 30(6):1286-1296. https://doi.org/10.1039/c4ja00471j

12. Dorofeev GA, Streletskii AN, Povstugar IV, Protasov AV, Elsukov EP (2012) Determination of nanoparticle sizes by X-ray diffraction. Colloid J 74(6):675-685. https://doi.org/10.1134/S1061933x12060051

13. Baalousha M, Lead JR (2012) Rationalizing nanomaterial sizes measured by atomic force microscopy, flow field-flow fractionation, and dynamic light scattering: sample preparation, polydispersity, and particle structure. Environ Sci Technol 46(11):6134-6142. https://doi.org/10.1021/es301167x

14. Cölfen H (2004) Analytical ultracentrifugation of nanoparticles. Polymer News 29(4):101-116. https://doi.org/10.1080/00323910490980840

15. Planken KL, Colfen H (2010) Analytical ultracentrifugation of colloids. Nanoscale 2(10):1849-1869. https://doi.org/10.1039/c0nr00215a 
16. Batsungnoen K, Riediker M, Suarez G, Hopf NB (2020) From nano to micrometer size particles - A characterization of airborne cement particles during construction activities. J Hazard Mater 398:122838. https://doi.org/10.1016/j.jhazmat.2020.122838

17. Brame JA, Alberts EM, Schubauer-Berigan MK, Dunn KH, Babik KR, Barnes E, Moser R, Poda AR, Kennedy AJ (2018) Characterization and workplace exposure assessment of nanomaterial released from a carbon nanotube-enabled anti-corrosive coating. Nanoimpact 12:58-68. https://doi.org/10.1016/j.impact.2018.10.002

18. Gohler D, Stintz M (2014) Granulometric characterization of airborne particulate release during spray application of nanoparticle-doped coatings. J Nanopart Res 16(8):2520. https://doi.org/10.1007/s11051-014-2520-1

19. Wang YF, Liu WZ, Li RZ, Zhang Y (2019) New insight into chemical changes between dissolved organic matter and environmental nano-CuO pollutants binding experiment using multispectroscopic techniques. J Mol Liq 291 https://doi.org/10.1016/j.molliq.2019.111278

20. Dini L, Panzarini E, Mariano S, Passeri D, Reggente M, Rossi M, Vergallo C (2015) Microscopies at the Nanoscale for Nano-Scale Drug Delivery Systems. Curr Drug Targets 16(13):1512-1530. https://doi.org/10.2174/1389450116666150531160851

21. Hill WB (2011) The Characterization of Nanoparticles Using Analytical Electron Microscopy. Proc Spie 8036 https://doi.org/10.1117/12.885115

22. Luo H, Xiang Y, Li Y, Zhao Y, Pan X (2021) Photocatalytic aging process of Nano-TiO2 coated polypropylene microplastics: Combining atomic force microscopy and infrared spectroscopy (AFMIR) for nanoscale chemical characterization. J Hazard Mater 404 (Pt B):124159 https://doi.org/10.1016/j.jhazmat.2020.124159

23. Bidram E, Sulistio A, Amini A, Fu Q, Qiao GG, Stewart A, Dunstan DE (2016) Fractionation of graphene oxide single nano-sheets in water-glycerol solutions using gradient centrifugation. Carbon 103:363371. https://doi.org/10.1016/j.carbon.2016.02.095

24. Lee JH, Han JH, Kim JH, Kim B, Bello D, Kim JK, Lee GH, Sohn EK, Lee K, Ahn K, Faustman EM, Yu IJ (2016) Exposure monitoring of graphene nanoplatelets manufacturing workplaces. Inhal Toxicol 28(6):281-291. https://doi.org/10.3109/08958378.2016.1163442

25. Tan P, Yang JJ, Nischwitz V (2020) A novel approach for determination of the dissolved and the particulate fractions in aqueous samples by flow field flow fractionation via online monitoring of both the cross flow and the detector flow using ICP-MS. J Anal Atom Spectrom 35(3):548-559. https://doi.org/10.1039/c9ja00313d

26. Grombe R, Allmaier G, Charoud-Got J, Dudkiewicz A, Emteborg H, Hofmann T, Larsen EH, Lehner A, Llinas M, Loeschner K, Molhave K, Peters RJ, Seghers J, Solans C, von der Kammer F, Wagner S, Weigel S, Linsinger TPJ (2015) Feasibility of the development of reference materials for the detection of Ag nanoparticles in food: neat dispersions and spiked chicken meat. Accredit Qual Assur 20(1):316. https://doi.org/10.1007/s00769-014-1100-5 
27. Weiss VU, Pogan R, Zoratto S, Bond KM, Boulanger P, Jarrold MF, Lyktey N, Pahl D, Puffler N, Schelhaas M, Selivanovitch E, Uetrecht C, Allmaier G (2019) Virus-like particle size and molecular weight/mass determination applying gas-phase electrophoresis (native nES GEMMA). Anal Bioanal Chem 411(23):5951-5962. https://doi.org/10.1007/s00216-019-01998-6

28. Weiss VU, Wieland K, Schwaighofer A, Lendl B, Allmaier G (2019) Native Nano-electrospray Differential Mobility Analyzer (nES GEMMA) Enables Size Selection of Liposomal Nanocarriers Combined with Subsequent Direct Spectroscopic Analysis. Anal Chem 91(6):3860-3868. https://doi.org/10.1021/acs.analchem.8b04252

29. Lim JH, Bairi VG, Linder SW, Fong A (2019) Detection and Characterization of Silver Nanostructures in Consumer Products. J Nanosci Nanotechnol 19(12):8078-8087. https://doi.org/10.1166/jnn.2019.16754

30. Schubert R, Meyer A, Dierks K, Kapis S, Reimer R, Einspahr H, Perbandt M, Betzel C (2015) Reliably distinguishing protein nanocrystals from amorphous precipitate by means of depolarized dynamic light scattering. J Appl Crystallogr 48:1476-1484. https://doi.org/10.1107/S1600576715014740

31. Boughbina-Portoles A, Sanjuan-Navarro L, Moliner-Martinez Y, Campins-Falco P (2021) Study of the Stability of Citrate Capped AgNPs in Several Environmental Water Matrices by Asymmetrical Flow Field Flow Fractionation. Nanomaterials (Basel) 11 (4) https://doi.org/10.3390/nano11040926

32. Irfan M, Uddin Z, Ahmad F, Rasheed A, Qadir MB, Ahmad S, Aykut Y, Nazir A (2021) Ecofriendly development of electrospun antibacterial membranes loaded with silver nanoparticles. J Ind Text. https://doi.org/10.1177/15280837211012590

33. Lin Z, Gao S, Yang JS, Qu Y, Zhang Z, He L (2021) A filtration-assisted approach to enhance optical detection of analytes and its application in food matrices. Food Chem 338:127814. https://doi.org/10.1016/j.foodchem.2020.127814

34. Chakraborty S, Nandy A, Ghosh S, Das NK, Parveen S, Datta S, Mukherjee S (2021) Protein-templated gold nanoclusters as specific bio-imaging probes for the detection of $\mathrm{Hg}$ (ii) ions in in vivo and in vitro systems: discriminating between MDA-MB-231 and MCF10A cells. Analyst 146(4):1455-1463. https://doi.org/10.1039/d0an02108c

35. Xiong G, Li SQ, Zhang YY, Buckley SG, Tse SD (2016) Phase-selective laser-induced breakdown spectroscopy of metal-oxide nanoparticle aerosols with secondary resonant excitation during flame synthesis. J Anal Atom Spectrom 31 (2):482-491 https://doi.org/Doi 10.1039/C5ja00186b

36. Barahimi V, Taheri RA, Mazaheri A, Moghimi H (2020) Fabrication of a novel antifouling TiO2/CPTES/metformin-PES nanocomposite membrane for removal of various organic pollutants and heavy metal ions from wastewater. Chem Pap 74(10):3545-3556. https://doi.org/10.1007/s11696-020-01178-2

37. Kirchner J, Anolleck JK, Losch H, Kureti S (2018) Methanation of CO2 on iron based catalysts. Appl Catal B-Environ 223:47-59. https://doi.org/10.1016/j.apcatb.2017.06.025

38. Kolawole FO, Varela LB, Kolawole SK, Ramirez MA, Tschiptschin AP (2021) Deposition and characterization of tungsten oxide (WO3) nanoparticles incorporated diamond-like carbon coatings 
using pulsed-DC PECVD. Mater Lett 282 https://doi.org/10.1016/j.matlet.2020.128645

39. Dasireddy VDBC, Hajduk S, Ruiz-Zepeda F, Kovac J, Likozar B, Orel ZC (2021) CeO2 and TiO2 support material effects on NH3 decomposition pathway mechanism over Cu-Zn catalysts. Fuel Process Technol 215 https://doi.org/10.1016/j.fuproc.2021.106752

40. Batsungnoen K, Riediker M, Suarez G, Hopf NB (2020) From nano to micrometer size particles - A characterization of airborne cement particles during construction activities. J Hazard Mater 398 https://doi.org/10.1016/j.jhazmat.2020.122838

41. Irshad MA, Nawaz R, Zia Ur Rehman M, Imran M, Ahmad J, Ahmad S, Inam A, Razzaq A, Rizwan M, Ali S (2020) Synthesis and characterization of titanium dioxide nanoparticles by chemical and green methods and their antifungal activities against wheat rust. Chemosphere 258:127352.

https://doi.org/10.1016/j.chemosphere.2020.127352

42. Geiss O, Bianchi I, Senaldi C, Bucher G, Verleysen E, Waegeneers N, Brassinne F, Mast J, Loeschner K, Vidmar J, Aureli F, Cubadda F, Raggi A, lacoponi F, Peters R, Undas A, Muller A, Meinhardt AK, Walz E, Graf V, Barrero-Moreno J (2021) Particle size analysis of pristine food-grade titanium dioxide and E 171 in confectionery products: Interlaboratory testing of a single-particle inductively coupled plasma mass spectrometry screening method and confirmation with transmission electron microscopy. Food Control 120:107550. https://doi.org/10.1016/j.foodcont.2020.107550

43. Yin MM, Chen WQ, Lu YQ, Han JY, Liu Y, Jiang FL (2020) A model beyond protein corona: thermodynamics and binding stoichiometries of the interactions between ultrasmall gold nanoclusters and proteins. Nanoscale 12(7):4573-4585. https://doi.org/10.1039/c9nr09170j

44. Alam MS, Zeraati-Rezaei S, Stark CP, Liang Z, Xu H, Harrison RM (2016) The characterisation of diesel exhaust particles - composition, size distribution and partitioning. Faraday Discuss 189:6984. https://doi.org/10.1039/c5fd00185d

45. Xu M, Chen Y, Hu WY, Liu YT, Zhang QP, Yuan H, Wang XY, Zhang JX, Luo KY, Li J, Xiong G (2020) Designed synthesis of microstructure and defect-controlled Cu-doped ZnO-Ag nanoparticles: exploring high-efficiency sunlight-driven photocatalysts. J Phys D Appl Phys 53 (2) https://doi.org/10.1088/1361-6463/ab4bfd

46. Wang F, Ma JZ, He GZ, Chen M, Zhang CB, He H (2018) Nanosize Effect of Al2O3 in Ag/Al2O3 Catalyst for the Selective Catalytic Oxidation of Ammonia. Acs Catal 8(4):2670-2682. https://doi.org/10.1021/acscatal.7b03799

47. Liu SN, Zheng M, Chen R, Wang ZS (2017) One-pot synthesis of an AgBr/ZnO hierarchical structure with enhanced photocatalytic capacity. Rsc Adv 7(50):31230-31238. https://doi.org/10.1039/c7ra03879h

48. Dulta K, Agceli GK, Chauhan P, Chauhan PK (2021) Biogenic Production and Characterization of CuO Nanoparticles by Carica papaya Leaves and Its Biocompatibility Applications. J Inorg Organomet P 31(4):1846-1857. https://doi.org/10.1007/s10904-020-01837-7

49. Benghnia A, Ares JR, Leardini F, Ben Slama R, Ayed B, Chaouachi B (2019) Synthesis and functionalization of graphite oxide: structural, morphological and thermal properties for hydrogen 
storage. J Mater Sci-Mater El 30(5):5044-5051. https://doi.org/10.1007/s10854-019-00802-6

50. Saladino GM, Vogt C, Li Y, Shaker K, Brodin B, Svenda M, Hertz HM, Toprak MS (2021) Optical and Xray Fluorescent Nanoparticles for Dual Mode Bioimaging. Acs Nano 15(3):5077-5085. https://doi.org/10.1021/acsnano.0c10127

51. Lakowicz JR (2013) Principles of fluorescence spectroscopy. Springer science \& business media

52. Du YY, Chen BJ, Pun EYB, Wang ZQ, Zhao X, Lin H (2015) Silver nanoparticles enhanced multichannel transition luminescence of $\mathrm{Pr} 3+$ in heavy metal germanium tellurite glasses. Opt Commun 334:203-207. https://doi.org/10.1016/j.optcom.2014.08.035

53. Luo SQ, Wang Q, Quan J, Yang M, Wang Y, Zhang X, Chen ZN (2021) A sky-blue luminescent silver(I) complex with a one-dimensional zipper-like structure constructed with 2-diphenylphosphinopyridine and thiocyanate. Transition Met Chem 46(5):415-421. https://doi.org/10.1007/s11243-021-00457-5

54. Shen F, Zhou G Ultra-fast luminescence of nano-gold film structure. In: Journal of Physics: Conference Series (2020) vol 1. IOP Publishing, p 012104

55. Xie YP, Shen YL, Duan GX, Han J, Zhang LP, Lu X (2020) Silver nanoclusters: synthesis, structures and photoluminescence. Materials Chemistry Frontiers 4(8):2205-2222. https://doi.org/10.1039/d0qm00117a

56. Candreva A, Di Maio G, La Deda M (2020) A quick one-step synthesis of luminescent gold nanospheres. Soft Matter 16(48):10865-10868. https://doi.org/10.1039/d0sm02024a

57. Crapanzano R, Villa I, Mostoni S, D'Arienzo M, Di Credico B, Fasoli M, Scotti R, Vedda A (2020) Morphology Related Defectiveness in ZnO Luminescence: From Bulk to Nano-Size. Nanomaterials (Basel) 10(10):1983. https://doi.org/10.3390/nano10101983

58. Huang Y, Fuksman L, Zheng J (2018) Luminescence mechanisms of ultrasmall gold nanoparticles. Dalton Trans 47(18):6267-6273. https://doi.org/10.1039/c8dt00420j

59. Tang CM, Sun F, Chen ZF, Yu HY, Chen DY, Liu ZW (2020) Facile synthesis and nanoscale related physical properties of core-shell structured $\mathrm{CuO} / \mathrm{ZnO}$ nanorods on Si substrate. Appl Surf Sci 509:144903. https://doi.org/10.1016/j.apsusc.2019.144903

60. Wu T, Li JY, Chang MQ, Song YH, Sun Q, Wang FK, Zou HF, Shi Z (2021) Photoluminescence properties and photocatalytic activities of SiO2@TiO2:Sm3 + nanomaterials. J Phys Chem Solids 149:109775. https://doi.org/10.1016/j.jpcs.2020.109775

61. Dinis $H$, Mendes $P$ (2020) A comprehensive review of powering methods used in state-of-the-art miniaturized implantable electronic devices. Biosensors Bioelectronics:112781 https://doi.org/10.1016/j.bios.2020.112781

62. Yeh P, Yeh N, Lee CH, Ding TJ (2017) Applications of LEDs in optical sensors and chemical sensing device for detection of biochemicals, heavy metals, and environmental nutrients. Renewable Sustainable Energy Reviews 75:461-468. https://doi.org/10.1016/j.rser.2016.11.011

63. Yildirim B, Dalmis R, Ertekin K, Birlik I, Azem FA (2020) Enhancing optical properties of Lu3Al5012:Ce3 + by cost-effective silica-based photonic crystals. J Mater Sci-Mater El 31(13):10267-10278. https://doi.org/10.1007/s10854-020-03573-7 
64. Yildirim B, Keskin OY, Oguzlar S, Birlik I, Azem FA, Ertekin K (2021) Manipulation of brightness and decay kinetics of LuAG: $\mathrm{Ce} 3+$ and YAG: $\mathrm{Ce} 3+$ by simple metal oxides in polymeric matrices. Optics Laser Technology 142:107226. https://doi.org/10.1016/j.optlastec.2021.107226

65. Skoog DA, Holler FJ, Crouch SR (2017) Principles of instrumental analysis. Cengage learning

66. Vashist SK, Luong JH (2018) Bioanalytical requirements and regulatory guidelines for immunoassays. In: Handbook of immunoassay technologies. Elsevier, pp 81-95

67. OSHA (2013) Working Safely with Nanomaterials Occupational Safety and Health Administration. https://www.osha.gov/sites/default/files/publications/OSHA_FS-3634.pdf. Accessed August 82021

\section{Figures}




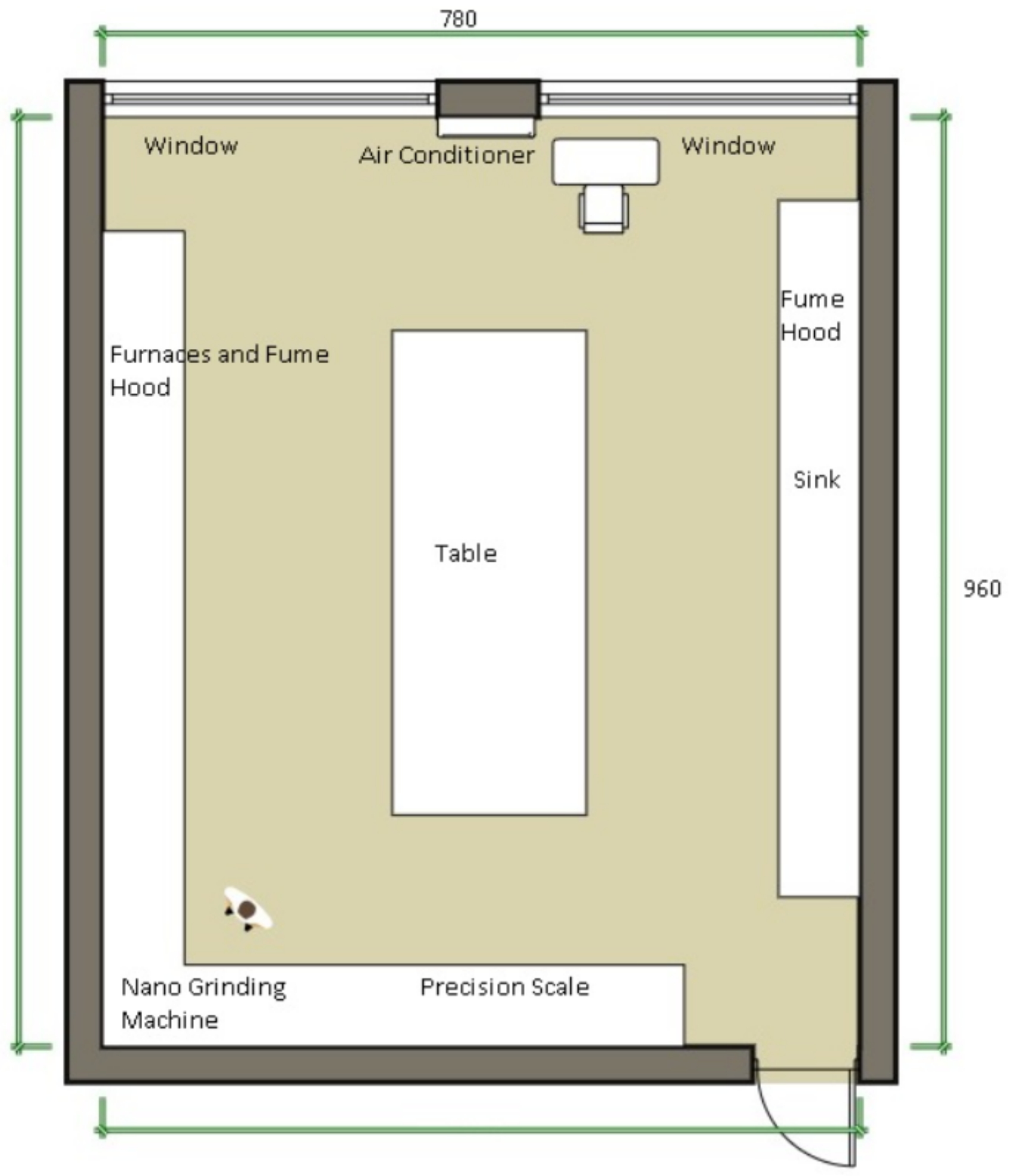

Figure 1

Schematic representation of the production laboratory 


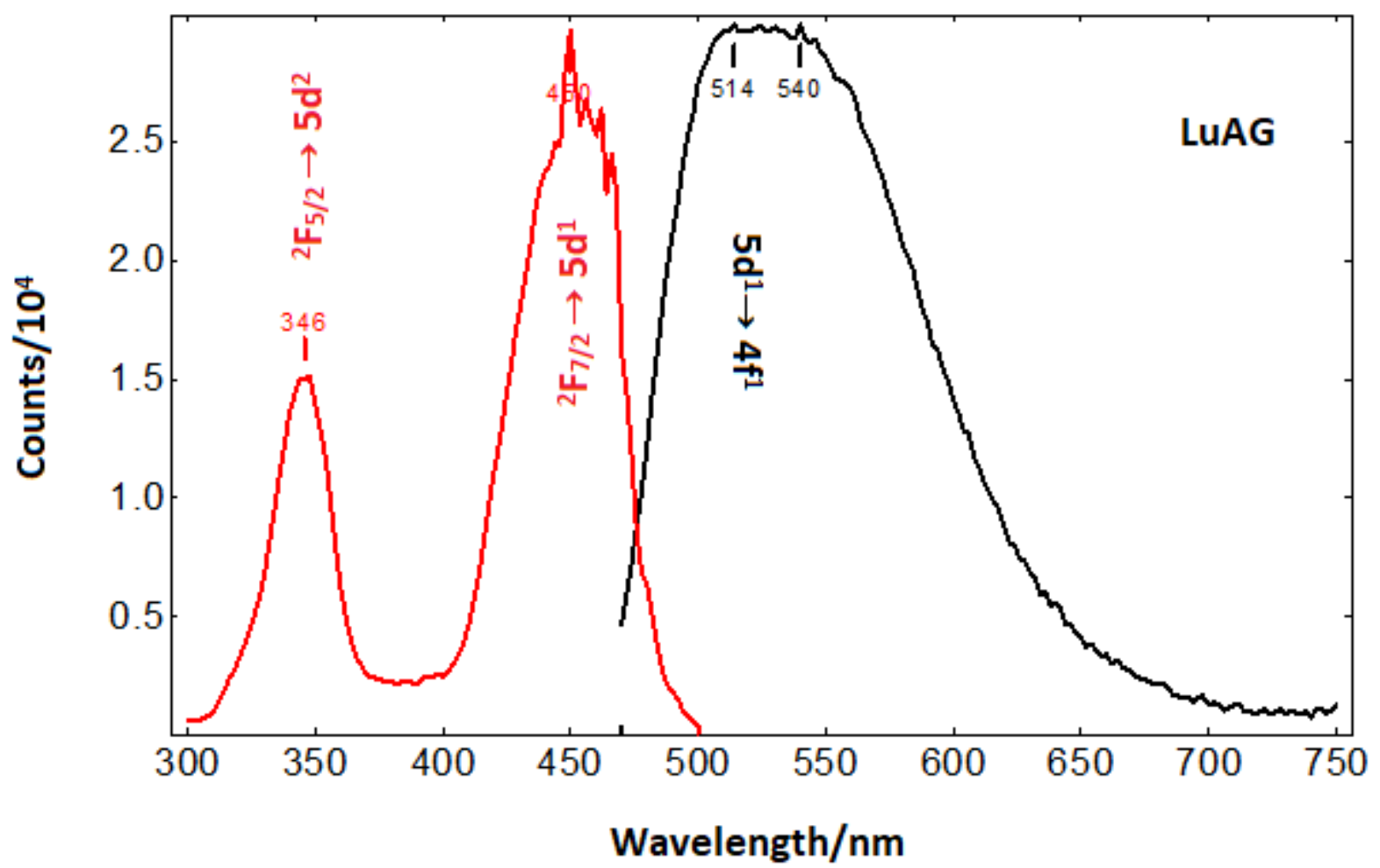

Figure 2

Excitation and emission spectra of the Ce3+ activated LuAG $(\lambda e x=450 \mathrm{~nm}, \lambda e m=514 \mathrm{~nm}, \lambda \mathrm{em}=540 \mathrm{~nm})$. 

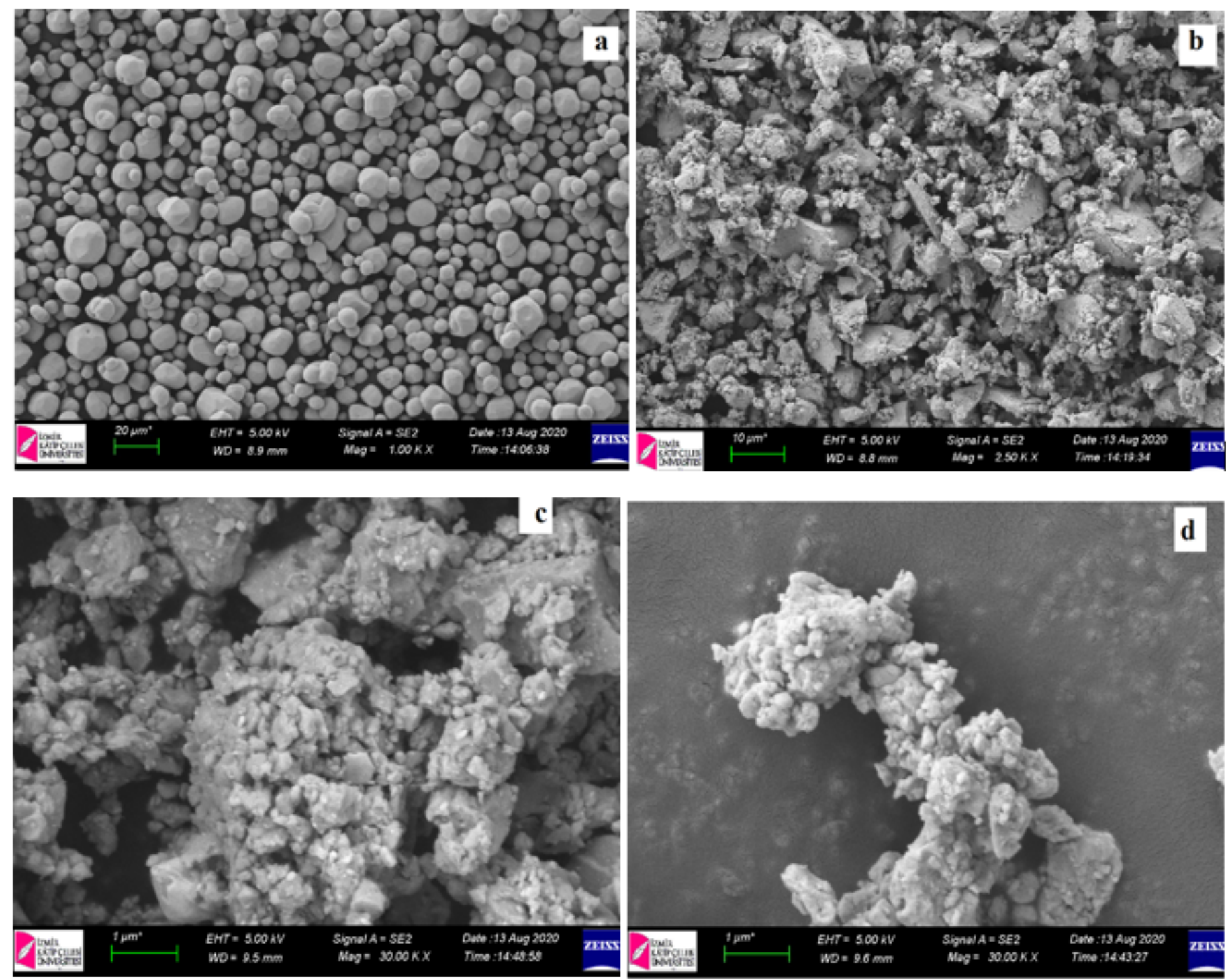

Figure 3

SEM photographs of the phosphor particles prior to (a) and after (b) 120, (c) 240 , and (d) 360 min. of grinding time, under different magnification. 
Size (d.nm... \% Intensity: St Dev (d.n...

Z-Average (d.nm): 1042

Peak 1: 1431

77,8

441,1

Pdl: 0,935

Peak 2: 232,7

12,8

58,42

Intercept: 0,819

Peak 3: 5265

9,4

434,2

Result quality Refer to quality report

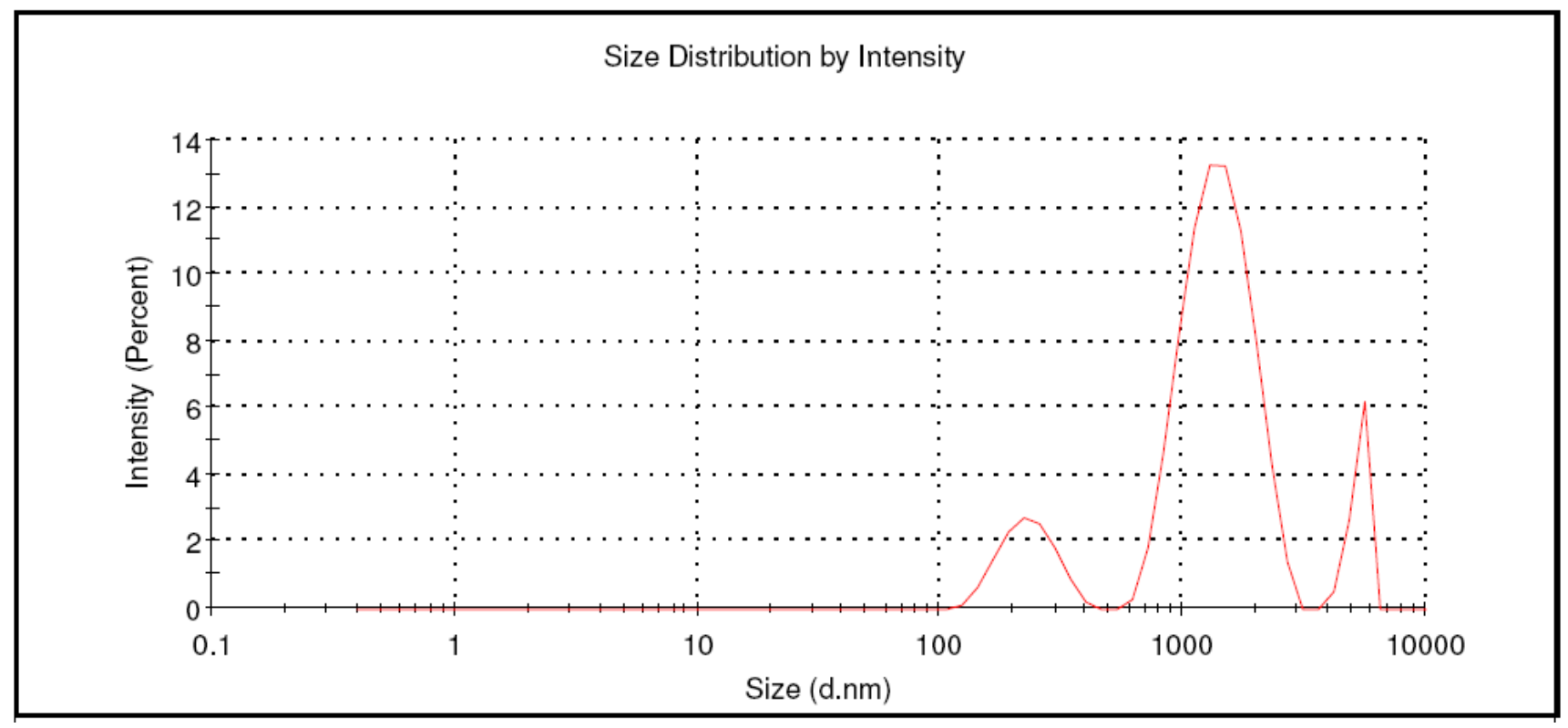

Figure 4

Size distribution analysis results of the Ce3+ activated LuAG particles after $360 \mathrm{~min}$. of grinding time. 

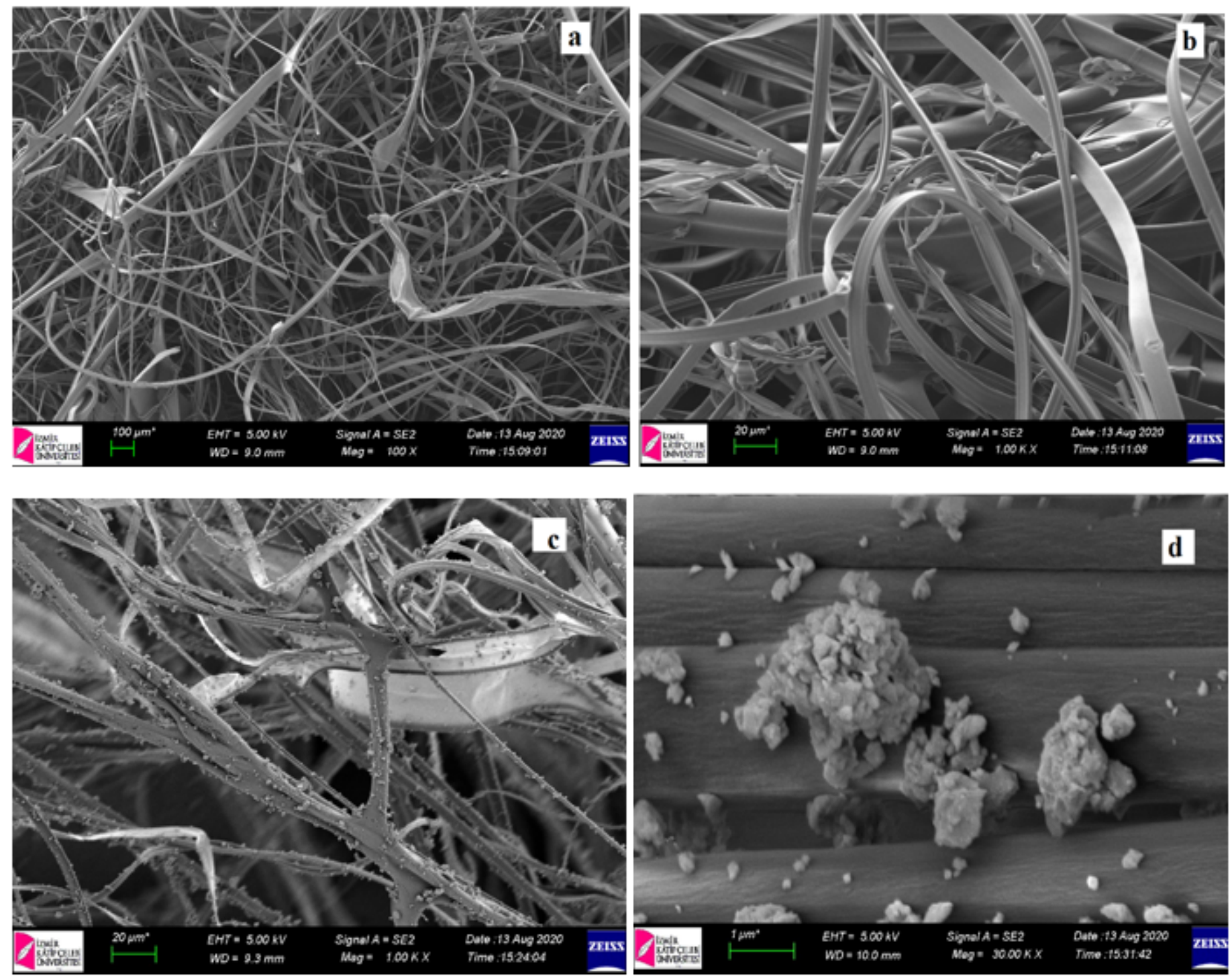

Figure 5

SEM photographs of the electrospun fibers under different magnification before ( $a$ and $b$ ) and after (c and $\mathrm{d}$ ) the $8 \mathrm{~h}$ filtration process. 

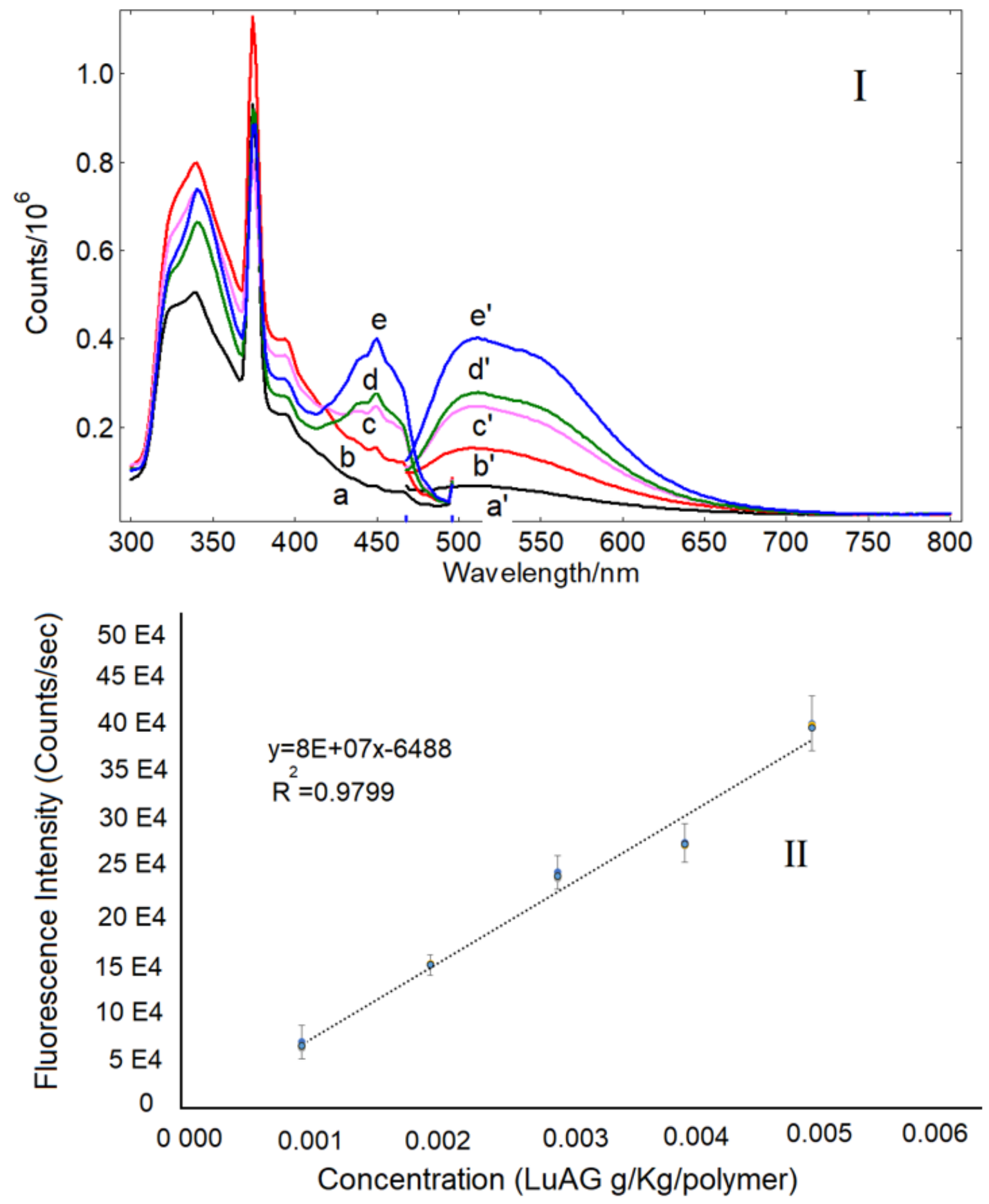

Figure 6

I: Excitation and emission spectra of the LuAG:Ce3+ doped thin films acquired for five different concentration points $(\lambda e x=450 \mathrm{~nm}, \lambda e m=512 \mathrm{~nm})$. II: Calibration plot including error bars. 


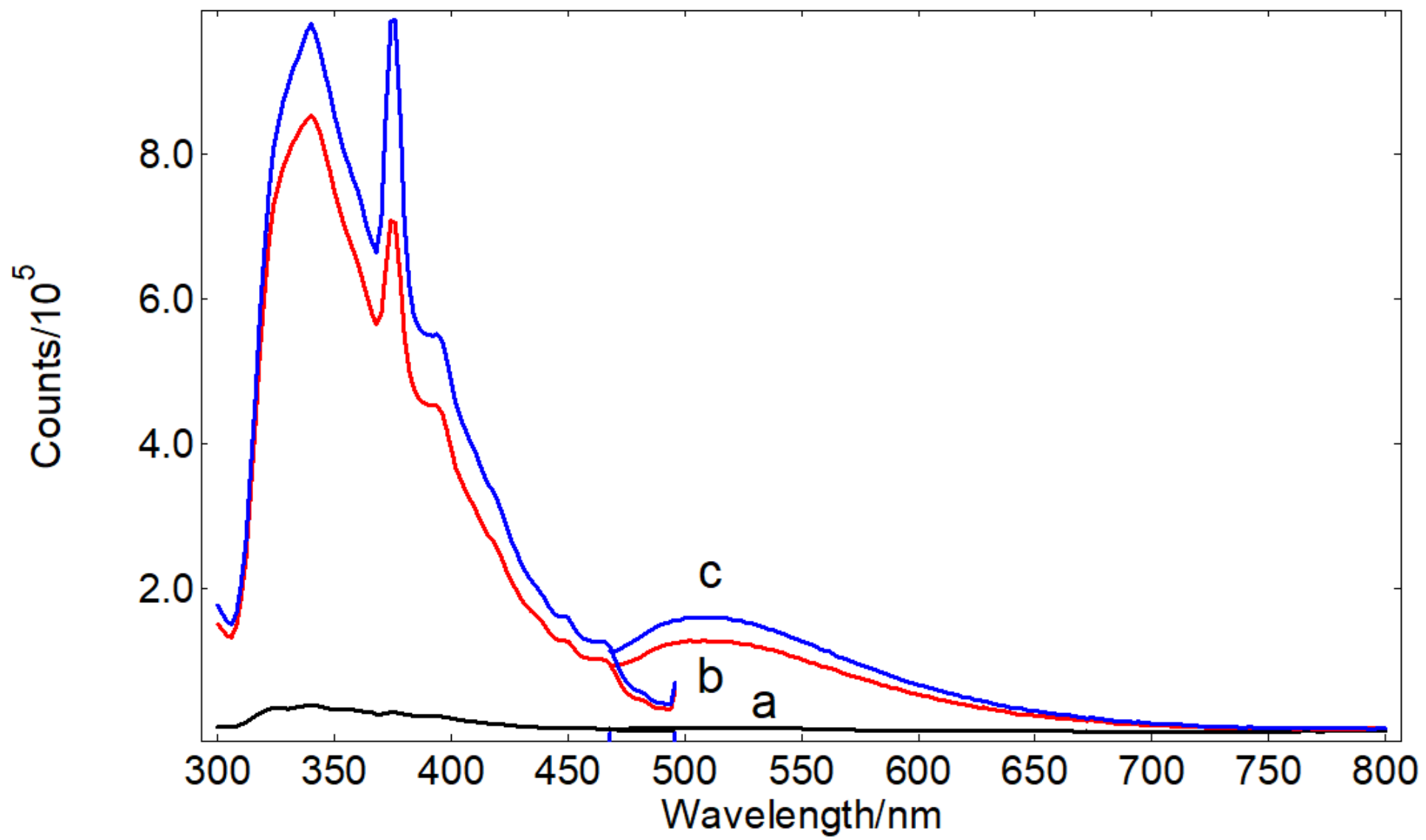

Figure 7

Excitation and emission spectra recorded for the real samples after grinding and handling durations of (a) 120, (b) 240 and (c) 360 min., respectively. 